\title{
Physical Activity During the Covid-19 Pandemic in the State Civil Apparatus of Gresik Regency
}

\author{
Abdul Hafidz ${ }^{1, *}$ Muhammad Zaky Purnomo ${ }^{2}$ Afif Rusdiawan ${ }^{3}$ \\ 1,2 Department of Sport Coaching Education, Universitas Negeri Surabaya, Surabaya, Indonesia \\ ${ }^{3}$ Department of Health Education and Recreation, Universitas Negeri Surabaya, Surabaya, Indonesia \\ ${ }^{*}$ Corresponding author.Email: abdulhafidz@unesa.ac.id
}

\begin{abstract}
This study aims to describe three subject points, namely: a) What sports activities are selected by the State Civil Apparatus of Gresik Regency during the pandemic Covid-19, b) What percentage of sports are dominantly carried out by Gresik Government Employees during the Covid-19pandemic, c) How much frequency of exercise the Civil Apparatus of the Gresik Regency Government before and during the Covid-19 pandemic. The type of research used is quantitative through a descriptive approach Exposure to the study results was obtained from collecting data from the dissemination of semi-open questionnaires online. Found field data as follows: a) Gymnastics, Basketball, Cycling, Volleyball, Badminton, Futsal, Road, Swimming, Fitness, Plank, Push Up, Static Bike, Running, Workout, Yoga, Squat Jump, Up-Down, Jogging, Tennis, Sit Up is a sports activity selected by Gresik Regency Government Employees. b) Jogging is a sports activity with a dominant percentage carried out by Gresik Regency Government Employees. c) During the pandemic, the physical activity of the Gresik district civil servants decreased, except for cycling and jogging. Furthermore, the frequency of exercise also tends to increase during a pandemic.
\end{abstract}

Keywords: Activity, State civil apparatus, Covid-19, Gresik, Pandemic.

\section{INTRODUCTION}

Most uses of the term pandemic refer to geographically widespread diseases. However, in addition to geographic extensions, most pandemic uses imply disease displacement or spread through a transmission that can move from one place to another, such as Covid-19 [1]

Physical activity is a body movement that requires energy or energy expenditure or burning calories [2]. Everyone performs physical activity based on individual lifestyle and other factors such as gender, age, work, etc. Physical activity is highly recommended to each individual to maintain health [3].

Sport is a systematic process in the form of all activities or efforts that can encourage, develop, and build the physical and spiritual potentials of a person as an individual or member of society in the form of games, competitions, and intensive physical activities to obtain recreation, development, and achievement [4]
According to Chen, P et al. (2020), one of the policy efforts in fighting pandemics is to increase endurance. "Stay at home" during the current period of lockdown or large-scale social restrictions should not stop society from doing physical activity and instead instill new creative ways of exercising and a more vital recognition of the importance of exercise [5]

The general goals and objectives of the training include: improving general and comprehensive essential physical qualities, developing and enhancing specific physical potential, adding and refining techniques, developing and perfecting strategies, tactics, and playing patterns, and improving the quality of athletes' mental abilities [6]

Some physical activity movements or exercises that can be done at home and their benefits, can be seen in table 1. 
Table 1. Some exercise at home or office

\begin{tabular}{|c|c|c|}
\hline Exercise & Frequency & Benefits \\
\hline \multicolumn{3}{|l|}{ Active dynamic warp up } \\
\hline \multirow{2}{*}{$\begin{array}{l}\text { High-knee-Butt Kicks-Lateral } \\
\text { Shuffles-Bodyweight squats }\end{array}$} & Beginner, $1-2$ sets of 10 reps & \multirow[t]{2}{*}{ Lower-body strength and power } \\
\hline & Advanced, $2-3$ sets of 20 reps & \\
\hline \multirow[t]{2}{*}{ Push-ups } & Beginner, $1-2$ sets of 10 reps & \multirow[t]{2}{*}{ Functional outcomes } \\
\hline & Advanced, $2-3$ sets of 20 reps & \\
\hline \multirow[t]{2}{*}{ Walking lunges } & Beginner, $1-2$ sets of 5 reps & \multirow[t]{2}{*}{ Upper-body strength and endurance } \\
\hline & Advanced, $2-3$ sets of 10 reps & \\
\hline \multirow[t]{2}{*}{ Planks } & Beginner, $1-2$ sets of 20 reps & \multirow[t]{2}{*}{ Hamstring strength and running speed } \\
\hline & Advanced, $2-3$ sets of 40 reps & \\
\hline \multirow[t]{2}{*}{ Jumping jacks } & Beginner, $1-2$ sets of 15 reps & \multirow{2}{*}{$\begin{array}{l}\text { Body posture, upper and lower body } \\
\text { isometric strength }\end{array}$} \\
\hline & Advanced, $2-3$ sets of 40 reps & \\
\hline \multirow[t]{2}{*}{ Sit-ups } & Beginner, $1-2$ sets of 15 reps & \multirow[t]{2}{*}{ Abdominal and core strength } \\
\hline & Advanced, $2-4$ sets of 20 reps & \\
\hline \multicolumn{3}{|l|}{ Colling down } \\
\hline $\begin{array}{l}\text { Static stretching and flexibility } \\
\text { exercise }\end{array}$ & & \\
\hline
\end{tabular}

According to Ganong (2001), the human body can fight all sorts of organisms or toxins that damage the body's tissues and organs. This ability is called immunity or immunity [7].

Moderate-intensity exercise can have an excellent immune impact, while at a high intensity (especially in people who are not conditioned) has implications for a drastic decrease in the ability of immune cells [8]. Some studies recommend doing vigorous-intensity exercise at least three times per week with a duration ranging from 20-60 minutes per day [9]

Most state civil servants work in front of the computer to forget to do physical activities, and their sedentary behavior increases. This is not good considering Trembley et al. (2016) suggest doing screen time for a maximum of 2 hours per day. Malm et al. (2019) also state that people who are less physically active have a greater risk of death than people who are more physically active [10]. Based on this, it is essential to research the level of physical activity of state civil servants, considering that now is a pandemic period that also affects physical activity due to restrictions on activities [11].

\section{METHODS}

This research refers to a type of quantitative research with a descriptive approach. Quantitative research refers to the reality of a symptom or phenomenon in a given population to test hypotheses through statistical measurement tools. The results of the data obtained are then processed and presented through a descriptive approach, namely by reviewing and describing the research results in the form of narratives and conclusion withdrawals [12].
The research location was conducted in the scope of the Gresik Regency Government with a population focus aimed at Gresik Government Employees who worked in the Gresik Regent's Office. The research time is scheduled with a span of 4 months, starting from the preparation of research to reports.

Determination of research subjects is done through purposive sampling techniques, where sampling techniques are based on specific considerations or criteria that have been known before [12]. In this case, the determination of the sample is aimed at the Gresik Government Employee who has a duty in the Gresik Regent's Office.

Based on data obtained from the Gresik District Staffing Agency, 451 employees are part of the work unit in the Gresik Regent's Office. So, the number of respondents who will be used as a sample is calculated based on the number of returnees.

Research instruments used in quantitative methods are measuring instruments that have a function in obtaining information related to the characteristics of research variables objectively [12]. The research instrument used in this study is the questionnaire.

The process of collecting data through research instruments in the form of questionnaires is carried out with several techniques as follows:

1. The preparation of a list of questions on the questionnaire is assembled based on the indicators of research variables.

2. The continuous questionnaire is then copied into the Google form.

3. Researchers determined the time span of charging, then spread the questionnaire to respondents conducted online (in the network). 
4. The data obtained from filling the questionnaire is then processed according to the researcher's needs.

Data analysis techniques in this study are presented in the quantitative descriptive form in the form of a percentage of data processing results in the field. This quantitative descriptive technique describes objects studied based on sample or population data without conducting analysis, and conclusions drawn are not generally applicable.

\section{RESULTS AND DISCUSSIONS}

This research was conducted by distributing online questionnaires through google forms that are explicitly shared for employees who have work units in the Gresik Regency Government. Out of a population of 451 employees.

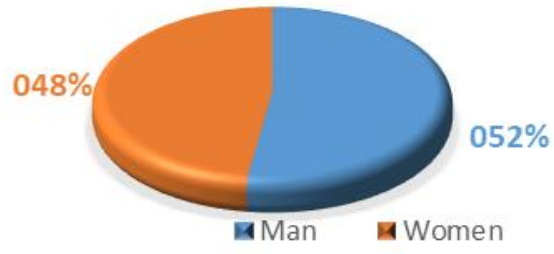

Figure 1 Gender of Respondents

It can be seen in Chart 1 that respondents consisted of male employees by $52.3 \%$ with 67 people and female employees by $47.7 \%$, with a total of 61 people.

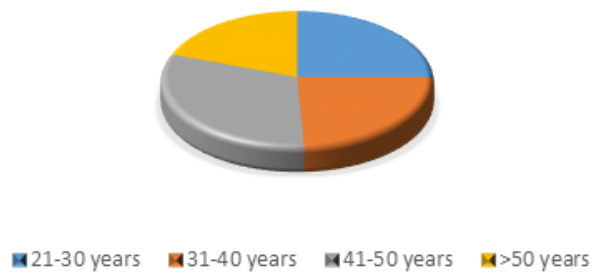

Figure 2 Ages of Respondents Chart

It can be seen in Figure 2 that respondents are dominated by employees aged $41-50$ years by $31.3 \%$, with a total of 40 people. Based on the age characteristics of respondents in Bagan 4.2, it shows that respondents aged between 21 - 30 years by $25.0 \%$ as many as 32 people, respondents aged $31-40$ years by $24.2 \%$ as many as 31 people, respondents aged 41 - 50 years by $31.3 \%$ as many as 40 people, and respondents aged over 50 years by $19.5 \%$ as many as 25 people.

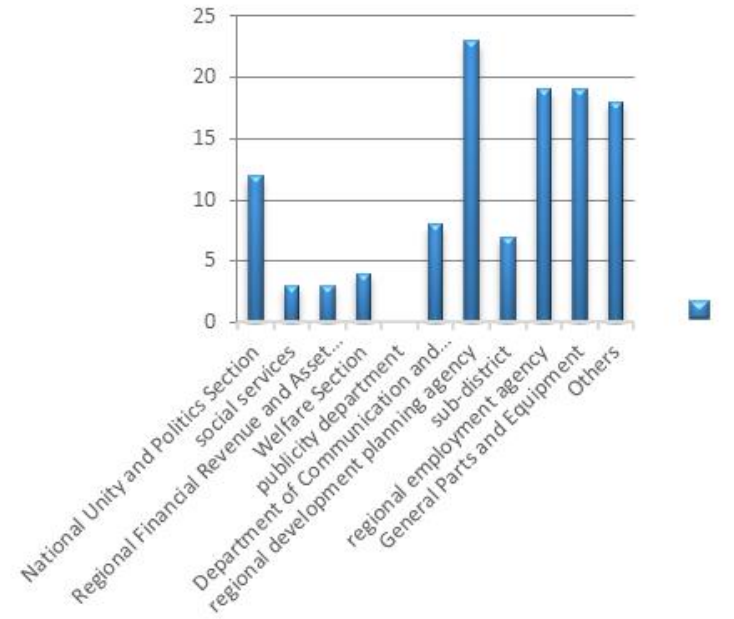

Figure 3 Where to Work

Based on Figure 3, all respondents came from various offices and sections in the Gresik Regency. Most respondents came from Bappeda by 18\%, which is 23 people out of 128 respondents. In addition, the Regional Staffing Agency and the General And Equipment Sections each amounted to $14.8 \%$ as many as 19 people. A total of 18 other respondents came from the National Unity and Politics Section, Social Department, Regional Financial Revenue and Asset Management Agency, Welfare Section, publicity department, Department of Communication and Information, sub-district, Regional employment agency, General Parts and Equipment, and others.

Respondents' characteristics based on the Covid-19 test experience can be seen in Figure 4 and Figure 5 .

Rapid test
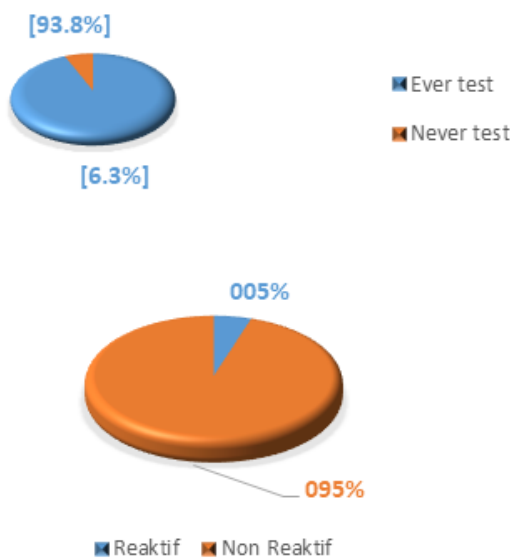

Figure 4 Rapid Test Experience

It can be seen in Figure 4 that as many as $93.8 \%$ of respondents with a total of 120 people have done Rapid Test with reactive results of $5 \%$, which is six people, while eight others have never done Rapid Test. In 
addition to rapid tests, other types of tests can identify a person affected by covid-19 or not, namely the swab test. Some respondents had done a SWAB Test, as shown in Figure 5.

Swab test

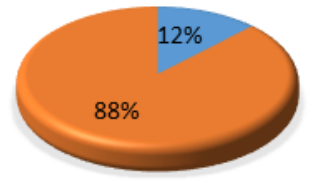

aver test

anevertes

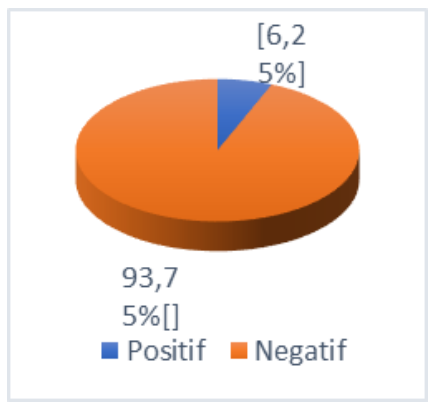

Figure 5 Swab Test Experience

It can be seen in Figure 5 that as many as $12.5 \%$ of respondents with the number of 16 people have done a SWAB Test with a positive result of $6.25 \%$, which is one person, while 112 others have never done a SWAB Test.

Everyone has the right to choose the sports they want. However, when the pandemic takes place, some limits must be adhered to prevent the transmission of Covid-19 so that the public must avoid sports that require many people, such as gymnastics and futsal. This led to changes in the selection of sports activities carried out by gresik government employees before and during the pandemic, as shown in Figure 6.

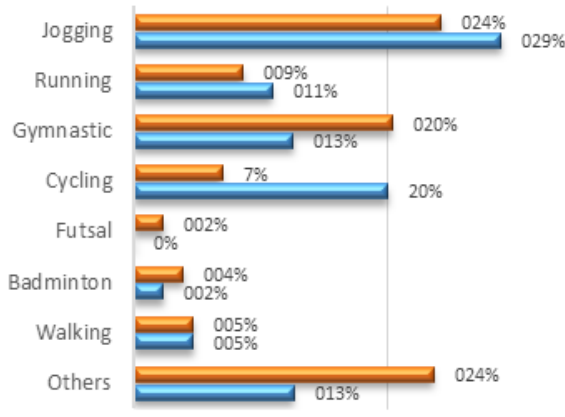

घAfter Pandemic घBefore Pandemic

Figure 6 Sports Activity Selection
It can be seen in Figure 6 that the dominant sports activity chosen is jogging both before the pandemic and during the pandemic. In contrast, the number of respondents who choose gymnastics, badminton, futsal, and other sports that require many people decreased. Respondents chose walking/running/jogging as many as 31 people before the pandemic and 37 respondents during the pandemic. In addition, there was an increase in respondents who chose road sports activities/running/jogging by $4.7 \%$. In addition to walking/running/jogging, cycling is also a type of sports activity widely chosen during pandemics. A total of 9 people chose cycling before the pandemic, and there was a $13 \%$ increase, which was 25 people who chose cycling during the pandemic. In addition to the sports activities that have been shown in Figure 6, other sports activities are the choice of respondents during the pandemic, namely workouts, sit-ups, push-ups, ups down, squat jump, basketball, treadmill, static bikes, and tennis.

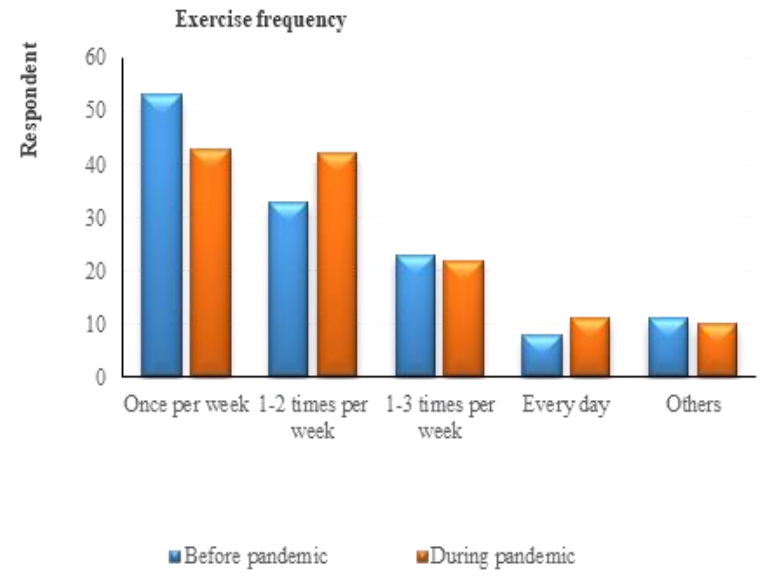

Figure 7 Frequency of Exercise

Figure 7 showed that 53 respondents were doing sports activities with a frequency of 1 time per week before the pandemic. However, during the pandemic, the activity of exercising with a frequency of 1 time per week decreased can be seen in Figure 7 frequency 1-2 times per week showed an increase with several reasons from respondents who want during the pandemic some things should be given more attention, namely health, fitness and maintaining stable immunity.

The dominant sport chosen by Gresik Government employees during the Covid-19 pandemic was Jogging. One of the benefits of jogging is that it can improve physical fitness[13]. In addition, Nabsakom et al. (2006) suggested that jogging effectively improves depression, stress, and fitness [14]. Jogging is often done together. Mueller et al. (2007) conducted an online survey, and the results were that $87 \%$ of people jogging together for socializing[15].

Various other sports activities that the Gresik Provincial Government employees also carry out during the Covid- 
19 pandemic can be seen in Figure 6. Most respondents chose the sport because it was easy to do during the Covid-19 pandemic. This is in line with the modification of sports activities that Gresik government employees can do during Work From Home (WFH).

\section{CONCLUSION}

Based on the study results, it can be concluded that the state civil apparatus of Gresik Regency, which consists of 451 employees with a percentage of $47.70 \%$ women and $52.30 \%$ men, has carried out rapid or swab tests. During the pandemic, the physical activity of the Gresik district civil servants decreased, except for cycling and jogging. Moreover, the frequency of exercise also tends to increase during a pandemic. This is due to the boredom experienced by the community regarding the limitation of activities

\section{ACKNOWLEDGMENTS}

Thank you to the Gresik district government for allowing this research

\section{REFERENCES}

[1] R. T. Handayani, D. Arradini, A. T. Darmayanti, A. Widiyanto, and J. T. Atmojo, "Pandemi covid-19, respon imun tubuh, dan herd immunity," J. Ilm. Stikes Kendal, vol. 10, no. 3, pp. 373-380, 2020.

[2] K. Manz and S. Krug, "Physical activity and health," Public Heal. Forum, vol. 21, no. 2, 2013, doi: 10.1016/j.phf.2013.03.012.

[3] M. Alricsson and Y. Kahlin, "Physical activity and health in adolescents," Sedentary Lifestyle Predict. Factors, Heal. Risks Physiol. Implic., vol. 15, no. 3, pp. 115-130, 2016.

[4] Department for Culture Media and Sport, "Sporting Future: A new strategy for an active nation," Dep. Educ. Ski., no. December, pp. 1-84, 2015.

[5] P. Chen, L. Mao, G. P. Nassis, P. Harmer, B. E. Ainsworth, and F. Li, "Coronavirus disease (COVID-19): The need to maintain regular physical activity while taking precautions," J. Sport Heal. Sci., vol. 9, no. 2, pp. 103-104, 2020, doi: 10.1016/j.jshs.2020.02.001.

[6] B. Chase, M. Hall, and T. A. Brusseau, "Impact of goal setting on physical activity in physical education," J. Phys. Educ. Sport, vol. 18, no. 2, pp. 757-761, 2018, doi: 10.7752/jpes.2018.02111.

[7] William F. J. and D. Ganong, Review of Medical Physiology 20th Edition, 20th ed. New York, 2001.

[8] D. C. Nieman and L. M. Wentz, "The compelling link between physical activity and the body's defense system," J. Sport Heal. Sci., vol. 8, no. 3, pp. 201-217, 2019, doi: 10.1016/j.jshs.2018.09.009.

[9] R. Komala, H. Riyadi, and D. B. Setiawan, "Latihan Intensitas Sedang Dan Berat Memperbaiki VO2 Max, Indeks Massa Tubuh, Dan Persen Lemak Tubuh Remaja Obes (Moderate and high exercise intensities improve VO 2 max, body mass index, and percent of body fat in obese adolescents)," J. Gizi Pangan, vol. 11, no. 3, pp. 211-218, 2016.

[10] C. Malm, J. Jakobsson, and A. Isaksson, "Physical Activity and Sports-Real Health Benefits: A Review with Insight into the Public Health of Sweden," Sports, vol. 7, no. 5, p. 127, 2019, doi: $10.3390 /$ sports7050127.

[11] V. Carson et al., "Systematic review of sedentary behaviour and health indicators in school-aged children and youth: An update," Appl. Physiol. Nutr. Metab., vol. 41, no. 6, pp. S240-S265, 2016, doi: 10.1139/apnm-2015-0630.

[12] A. Maksum, Meteodologi Penelitian Dalam Olahraga. Surabaya: Unesa University Press, 2014.

[13] A. Agus and M. P. Sari, "The Impact of Jogging on the Improvement of Physical Fitness," Proc. 1st Prog. Soc. Sci. Humanit. Educ. Res. Symp. (PSSHERS 2019), vol. 464, no. Psshers 2019, pp. 896-901, 2020, doi: 10.2991/assehr.k.200824.199.

[14] C. Nabkasorn et al., "Effects of physical exercise on depression, neuroendocrine stress hormones and physiological fitness in adolescent females with depressive symptoms," Eur. J. Public Health, vol. 16, no. 2, pp. 179-184, 2006, doi: 10.1093/eurpub/cki159.

[15] F. Mueller, S. O'Brien, and A. Thorogood, "Jogging over a distance: Supporting a 'jogging together' experience although being apart," Conf. Hum. Factors Comput. Syst. - Proc., no. January, pp. 2579-2584, 2007, doi: 10.1145/1240866.1241045. 